\title{
Dominant Party Adaptation to the Catch-All Model: a Comparison of Former Dominant Parties in Japan and South Korea
}

\author{
Sean Vincent ${ }^{1}$
}

Received: 6 March 2017 / Accepted: 20 July 2017 / Published online: 5 August 2017

(C) The Author(s) 2017. This article is an open access publication

\begin{abstract}
In the process of democratisation, it is expected that a former dominant party, at least one which abides by the rules of electoral contestation, will transition into a "catch-all" party. A catch-all party aims to attract the votes of all social cleavages and classes of voters outside what would be considered their traditional voter base. As part of the wider debate about democratisation in East Asia, this paper examines how two of East Asia's liberal democracies - Japan and South Korea, the LDP and GNP/Saenuri, respectively, have adapted to electoral defeat and in what ways they have transitioned into catch-all parties in the Kircheimer mould. This paper finds that while intra-party reforms which could fit a catch-all model have yet to be institutionalised, data from the Comparative Manifesto Database shows that there has been a significant change in which policies both parties promote and that these are designed to appeal to a broad base of voters.
\end{abstract}

Keywords Dominant parties $\cdot$ Catch-all parties $\cdot$ East Asian politics $\cdot$ Party organisation

\section{Introduction}

In the process of democratisation can be expected that a former dominant party will transition into a "catch-all" party model, an idea first formulated by Otto Kirchheimer [1]. The catch-all party aims to attract votes from all social cleavages and classes of voters outside what would be considered their traditional voter base. As part of the wider debate about democratisation in East Asia, this study examines two of East Asia's liberal democracies - Japan and South Korea_ and how their former dominant parties

Sean Vincent

s.vincent@sussex.ac.uk

1 University of Sussex, Sussex, UK 
adapted to electoral defeat and in what ways they have become catch-all parties in the Kircheimer mould.

Many countries in East Asia were subject to dominant party rule during the second half of the twentieth century. In the case of Japan, the region's first liberal democracy, the dominance of the Liberal Democratic Party (LDP) from 1955 until 1993 and then again from 1996 until 2009, has led some commentators to describe the LDP as the most successful political party in the democratic world. Unlike many examples of dominant parties in East Asia, the post-war dominance of the LDP was achieved against a backdrop of free and fair electoral contestation. Through a combination of clientelism, favourable economic circumstance and an electoral system which fostered intra-party competition, the LDP were able to hold onto power, almost uninterrupted, for over 50 years $[2,3]$.

In Korea, the first free legislative elections were held in 1988 and won by the Democratic Justice Party, the successor to the Democratic Republican Party which had been the largest party in the legislature since authoritarian rule was established in 1963. From 1988 until 2012, this party would go through a number of mergers and name changes: from the Democratic Liberal Party, to New Korea, to the Grand National Party (GNP) and eventually to the Saenuri Party. Despite the mergers and name changes, this remained very much the same conservative coalition which was continuously the largest party in the legislature, from 1963 until 2004, and had control of the Presidency until 1997 [4].

This paper examines how both conservative parties in Japan and South Korea adapted to losing their preeminent position through adopting "catch-all" party organisational models and policy platforms. In the case of the LDP, this study will focus on how the party has reformed internally since their first legislative defeat in 1993. In the case of South Korea, this study will examine party reforms made by the Grand National and Saenuri parties, the conservative party successors of the authoritarian and post-authoritarian ruling parties, which were brought on in the wake of the defeat of the GNP in the 1997 Presidential and 2004 legislative elections [4]. This paper works under the assumption that it is electoral defeat and the loss of dominant party status which incentivises parties to adopt a catch-all model [5]. It is the GNP which had to adapt in the wake losing both the Presidential and legislative elections for the first time. As this paper is concerned with how former dominant parties adapt in the wake of electoral defeat, it is the reforms GNP and Saenuri parties rather than their earlier incarnations which are most likely to display any potential movement towards a catchall model and thus are of most relevance to this study. ${ }^{1}$

\section{Transitioning from a Dominant to Catch-All Party}

In Uncommon Democracies [6], Pemple examined dominant parties across a range of countries. Against the backdrop of the end of the Cold War, Pempel argued that former authoritarian parties, seen in Eastern Europe, East Asia and Latin America, transitioned to an electoral democratic system while maintaining their control of state resources to

\footnotetext{
${ }^{1}$ From here, where appropriate, the GNP/Saenuri parties will be classed as one entity, representing the main conservative party of South Korea
} 
ensure success at the ballot box. A contemporary example of this can be seen in Singapore, where the People's Action Party has ruled uninterrupted since 1959 and opposition parties, while competing in a system of free and fair elections, have no realistic chance of winning power thanks to the PAP-bureaucratic alliance [7]. East Asia in particular provides an alternative to the development of western democracy, as parties were not created in line with traditional voter-cleavages. ${ }^{2}$ Instead more homogeneous societies have fostered the continued power of dominant parties [9].

Kirchheimer [1], writing about the political parties of western Europe, set out the features of the post-war catch-all party. In contrast to the Lipset-Rokkan paradigm, party appeal in industrially advanced countries, with the rise of the middle classes, could no longer be based on elite or ideological boundaries but must give individuals and members a stake in determining both the leadership and policies of the party. Parties must place emphasis on policies which appeal to multiple social cleavages and are unlikely to meet widespread public resistance [1]. This was subsequently developed further by Gunther and Diamond, whose definition of a catch-all party can be seen in Table 1, and Panebianco [11], who stressed the professionalisation of parties resulting in weak ties to membership. Under the system of universal enfranchisement and economic modernisation, professional political parties have become office-seeking entities, rather than being issue or cleavage based relying on a core set of supporters who share the same interests as the party [10].

Moreover, catch-all parties wish to avoid being perceived by voters as occupying an extreme left-right ideological position which could deter the median voter, who increasingly identify as ideologically centrist [12].

\section{Research Goals and Case Selection}

Using Kirchheimer's theory that political parties in industrialised liberal democracies will adopt policies and practices intended to appeal to the widest base of voters possible, this study examines two key areas of dominant party change in the LDP and GNP/Saenuri after their time as dominant powers came to an end, making two theoretical assumptions:

- The LDP and GNP/Saenuri parties will have made intra-party processes more transparent and inclusive through organisational changes in the areas of central party organisation, legislative candidate selection and party financing

- The LDP and GNP/Saenuri will have adopted more centrist policy positions, in comparison to their time as dominant parties, with more focus on economic and welfare policies designed to appeal to centrist voters

The focus of this study is to establish which catch-all party characteristics the LDP and GNP/Saenuri have adopted in the period since their first electoral defeat. The writings of party theorists such as Kirchheimer, Sartori and Duverger [13] were focused on Western European states and so far, the examination of Asia's liberal democracies remains underdeveloped. Comparative texts which study the political parties of East

\footnotetext{
${ }^{2}$ See [8]
} 
Table 1 Features of catch-all parties

\begin{tabular}{llll}
\hline Goal & Electoral strategy & Organisational structure and linkage & Social base \\
\hline $\begin{array}{c}\text { Maximise electoral } \\
\text { support through } \\
\text { broad aggregation } \\
\text { of interests }\end{array}$ & $\begin{array}{c}\text { Votes through } \\
\text { broad issue } \\
\text { appeal and } \\
\text { candidate } \\
\text { image }\end{array}$ & $\begin{array}{c}\text { Organised around election } \\
\text { campaigns, with otherwise weak } \\
\text { organisation. Weak and shifting } \\
\text { linkages with civil society }\end{array}$ & $\begin{array}{c}\text { Core social group with } \\
\text { shifting base whose } \\
\text { support is needed for } \\
\text { electoral victory }\end{array}$ \\
\hline
\end{tabular}

Based upon definitions set out by Diamond and Gunther p. 11 [10]

Asia have either yet to attach the same parameters of study to each country or move beyond the process of democratisation rather than treat their subjects as fully developed liberal democracies $[5,14,15]$. By studying existing liberal democracies in East Asia, this paper may also provide an indication of the future democratic development of other states in the region where the process of democratisation remains incomplete.

Both Japan and South Korea represent examples of liberal democracies in East Asia but represent two very different patterns of democratic development. Japan has been an established liberal democracy since the end of the Second World War with a political party system which dates back much further. In comparison, South Korea's journey to democracy, as part of the "Third Wave", has been relatively recent, with 1987 being the first time a president was democratically elected in a free election [16]. Moreover, Japan and South Korea represent parliamentary and presidential systems, respectively. In looking at regional trends in democratic development, it is important to examine different systems while accounting for the possible effect systemic differences have on political party organisation. As an example, one may expect parties to be weaker in presidential systems as much of their policy is developed top-down, with the party leader setting the agenda [17].

\section{Research Design and Methodology}

The study focuses on two core areas: party organisation and the evolution of policy and ideology of the LDP and GNP/Saenuri after both parties had suffered their first electoral defeat-1993 and 1997, respectively.

Party organisation: The first section will examine intra-party changes made by both parties in the wake of their electoral defeat using a number of primary and secondary sources, including party publications, media reports and scholarly analysis. In becoming catch-all parties, it can be expected that former dominant parties will become more transparent in their candidate and leadership selection process and more inclusive in an attempt to widen their voter base $[1,5]$.

Policy and ideology: Party policy changes and ideological positioning will be judged using data from the Comparative Manifesto Project Database (CMP). The CMP uses a content analysis of political party manifestos for each general election to ascertain which policies are considered most important by the party and judges overall party positions on a left-right ideational scale (RILE). In becoming catch-all parties, it can be expected that parties will not only favour more centerist policy positions but also pursue a policy agenda which, ideologically, is similar to the main opposition party they contest elections against, which should be the case in two-party systems. 


\section{Party Organisation}

Kirchheimer's original typology of catch-all party organisation has been accused of underdevelopment, especially when assessing the role of party leadership and linkages with society. In analysing the political parties of Western Europe, Wolinetz [18] describes the catch-all party as being essentially a vote-seeking entity-sacrificing traditional support and ideology in favour of broad-based appeal. As highlighted earlier by Diamond and Gunther (see Table 1), the catch-all/vote-seeking party would expect to have a weak organisational structure made up of party professionals and candidates, only mobilising member support at election time. Party activity would be limited mainly to elections and remain relatively dormant the rest of the time. Panebianco [11] goes into further detail by describing the transformation from the mass bureaucratic party which would typify a non-authoritarian dominant party, to an electoral professional party, closest to the catch-all model. In organisational terms, the electoral professional party can expect to have weaker vertical ties between party leadership and its members, receive funding based on public or interest group sources and have major party operations and policy formulation decided by leadership and public representatives rather than unaccountable party insiders behind closed doors. Diamond and Gunther [10] also set out the organisational traits specifically relating to the catch-all party - that candidate nomination will be based on a potential candidate's personal appeal to voters rather than formal selection by party institutions/leadership and electoral mobilisation will be based on direct appeal to the public, through modes of mass-communication, rather than through grass roots party organisations. Catch-all parties will have limited potential for social integration as they are less focussed on being identified by specific social groups and more with broad appeal thus becoming more beholden to central party financing.

Based on existing theories surrounding catch-all party organisation, the following section will examine changes in LDP and GNP/Saenuri (including the party's precursors) organisation from their time as dominant parties to the present day to assess what catch-all party characteristics they have adopted in their respective post-dominant party systems. To do this, a general framework of both parties is set out in the following areas: central party organisation, candidate nomination procedure and party affiliation and financing. A summary of the findings can be seen in Table 2:

\section{Central Party Organisation}

\section{The LDP}

In 1955, the Democratic Party and the Liberal party united to form the LDP and in doing so created what became known as the "1955 System". From 1955 until 1993, the LDP was able to win an outright majority or form a coalition government in which it was the dominant force. According to Krauss and Pekkanen, factions within the LDP became institutionalised in the 1970s and took over control of policy formation and leadership selection [3]. The LDP's control over resources and factional make-up meant that policy formation was made through intra-party negotiations rather than through legislative debate. The main forum for these negotiations was the party's Policy Affairs 
Table 2 Summary of catch-all organisational traits in LDP and GNP/Saenuri

\begin{tabular}{|c|c|c|c|}
\hline & Catch-all party & Liberal Democratic Party & Grand National Party/Saenuri \\
\hline $\begin{array}{l}\text { Central party } \\
\text { organisation }\end{array}$ & $\begin{array}{l}\text {-Leadership responsible for } \\
\text { policy and party organisation } \\
\text {-Leadership selection } \\
\text { decentralised to membership } \\
\text {-Weak ties to membership_based } \\
\text { on electoral mobilisation }\end{array}$ & $\begin{array}{l}\text {-Leader's role in party } \\
\text { organisation not } \\
\text { institutionalised } \\
\text {-Factional influence } \\
\text {-Progressive } \\
\text { decentralisation } \\
\text { of leadership selection } \\
\text {-Weak party ties to } \\
\text { membership }\end{array}$ & $\begin{array}{l}\text {-Leadership has decisive } \\
\text { voice in party matters } \\
\text {-Progressive decentralisation } \\
\text { of leadership selection } \\
\text {-Strong regional ties. eakening } \\
\text { party ties to individual } \\
\text { membership }\end{array}$ \\
\hline $\begin{array}{l}\text { Candidate } \\
\text { nomination }\end{array}$ & $\begin{array}{l}\text { Increasingly centralised_-based } \\
\text { on candidates' personal } \\
\text { appeal/strengths }\end{array}$ & $\begin{array}{l}\text { Pragmatic_-based on } \\
\text { candidates' ability to } \\
\text { win/individual } \\
\text { strengths }\end{array}$ & $\begin{array}{c}\text { Centrally controlled-based on } \\
\text { party leadership decisions }\end{array}$ \\
\hline $\begin{array}{l}\text { Financing and } \\
\text { affiliation }\end{array}$ & $\begin{array}{l}\text { - Direct public or interest group } \\
\text { funding } \\
\text { - Direct party appeal, weak } \\
\text { social integration }\end{array}$ & $\begin{array}{l}\text { - Combination of public } \\
\text { financing to party and } \\
\text { donations to local } \\
\text { candidates } \\
\text { - Direct candidate appeal, } \\
\text { weak social } \\
\text { integration }\end{array}$ & $\begin{array}{l}\text { - Combination of public } \\
\text { financing to party and } \\
\text { private donations to local } \\
\text { candidates } \\
\text { - Party/regional appeal. } \\
\text { Growing links with civil } \\
\text { society }\end{array}$ \\
\hline
\end{tabular}

Research Council (PARC). PARC decentralised policy formulation, away from the Prime Minister's and Cabinet office. Positions within PARC were also appointed by consensus, with senior members of factions able to both occupy and allocate positions based on factional strength. Under this system, policy was essentially made in PARC or other less-formal avenues of negotiation, intra-party consensus was reached along with bureaucratic and special interest groups and assured of passage within the Diet [2]. The leaders of political parties, especially in a Parliamentary system, theoretically have a great deal of influence over candidate nomination, funding, polices and the allocation of Cabinet/party posts. However, this power was stifled under the faction centred 1955 system and the power of the Prime Minister was limited to control over Diet vote scheduling and a greater influence in foreign policy affairs [3]. Leadership selection was decided in much the same way as policy formulation. Party leaders were selected on the basis of factional negotiation but were then obliged to appoint Cabinet and other governmental positions based on factional strength. According to the LDP Constitution, the LDP Party Convention, consisting of all Diet members and delegates from party branches, is responsible for the election of the party President. ${ }^{3}$ However with the high resignation rate of LDP Prime Ministers, the party has the power to appoint party leaders under "extraordinary circumstances". 4 Out of the last 22 LDP leaders, 7 have been chosen without a vote at the Convention [19].

Since the LDP's 1993 election defeat, there have been attempts at structural party change at a leadership level but few which have had lasting success. In the immediate

\footnotetext{
${ }^{3}$ Article 6 of the LDP Constitution: https://www.jimin.jp/english/about-ldp/constitution/104146.html

${ }^{4}$ Prior to the second election of Shinzo Abe as leader of the LDP, there had been 16 Prime Ministers since the beginning of the Heisei period (from 1989 onwards).
} 
aftermath of their defeat, the LDP was able to take advantage of the instability of the Japanese Socialist Party-led coalition to return to government as part of a coalition themselves in 1994 and win a Diet majority in 1996 [20]. In 1996, the Hashimoto administration set up the Council on Administrative Reform in an attempt to loosen the close ties between party leadership and the bureaucracy which had come to light after multiple scandals in the 1990s [21]. Hashimoto's reforms were not passed until 2001 and faced intra-party opposition but eventually succeeded in strengthening leadership through the establishment of the Cabinet Office which gave the Prime Minister a larger and more professional staff and allowed the Prime Minister legal authority to initiate policymaking. The Koizumi administration, from April 2001 until September 2006, had great success in seeing off vested interests in passing landmark postal reform and further strengthening the Cabinet Office. Many candidates were elected for the first time based on the strength of party identification rather than local or personal ties [22]. Koizumi overcame intra-party opposition to his reforms by going directly to the electorate and making the 2005 general election about his personal appeal vs. old guard LDP factions [6]. However, without the personal leadership of Koizumi, strengthening of the Prime Minister's office at the expense of factions has not become institutionalised. Babb makes the case that parties in Japan, which pre-1994 were ideologically more homogenous due to national security issues, have become internally more diverse [19]. While Babb argues, this is part of factional decline, Theis [23] adds that while ideological splits are appearing, and electoral financing reform has theoretically lessened individual lawmakers' reliance on factional support, factions still play a vital role in members' career advancement and intra-party politics at the central level. The leadership election of 2012 also highlights the continued power of the parliamentary party at the expense of membership. In the first round of voting, open to all members, eventual winner Shinzo Abe won a majority of votes in only 6 out of 47 prefectures. However, as his main rival Shigeru Ishiba was unable to win 55\% in the first round of voting, a run-off in which only LDP Diet members were eligible to vote was held and the factionally unaligned Ishiba was defeated [24]. The power of party membership in leadership selection may have become institutionalised but has yet to become a consistently decisive factor.

\section{GNP/Saenuri}

Traditionally, political parties in South Korea have been characterised by the identity of their leader. The change in political party branding coming with new leadership, most obvious in the progression of the conservative party which is the focus of this study, is an example of how important personal, charismatic leadership is in Korean politics. The GNP's predecessor, the Democratic Justice Party, was able to establish its position as a dominant party thanks to a combination of authoritarian rule, control over the resources of the state and a growing economy. This established clientelistic network was successfully carried over after 1988 and ensured conservatives remained the largest single party in the National Assembly until 2004. In contrast to the LDP model, GNP factions were under the control of the party leader, on whom they relied for resource allocation and candidate selection [25]. Under the dominant party system, the President was de facto head of the party and as such had final say on intra-party policy formulation, as well as the power of Executive Order over the National Assembly itself [4]. In short, the party was characterised by strong top-down personal leadership. 
Intra-party reform was brought about by Lee Hoi-Chang's defeat in the 1997 Presidential election. This was seen as the end of the "three Kim's era" which had dominated Korean politics after 1988. Narrow defeat in the 1997 and 2002 Presidential elections (by 1.6 and $2.32 \%$, respectively) has been attributed to the power vacuum left after Kim Young-Sam's term and his control over the GNP effectively ended [4]. During the period between 1997 and 2002, the GNP was wracked by factional infighting, with no clear leadership, the party's modus operandi became about attacking Kim Dae-Jung's economic policy failures or the corruption charges brought against his successor Roh Moo-hyun rather than formulating policy that appealed to the wider voting public [26]. Party leadership and policy positions were decided through factional consensus. In 2007, Lee Myung-Bak, a former CEO of Hyundai and mayor of Seoul, sought the GNP's nomination for leadership over the more established Park Geun-hye, daughter of former president and future President, Park Chung-hee and leader of the biggest GNP faction in the National Assembly. In an effort to overcome the established clientelistic network of support enjoyed by the party's old guard, Lee negotiated a change in presidential candidate nomination with Park. The overall "selectorate" was 232,000 people $-50 \%$ made up of party members and 50\% from randomly chosen, unaffiliated voters from telephone and focus group interviews. It was the independent votes, over the party member votes which favoured Park, which secured the nomination for Lee [25]. This independent legitimacy was enough to get Lee selected but not enough to re-establish central control of the party. In 2008, supporters of Park in the legislature officially left the GNP and formed what would be known as the Pro-Park Coalition which went on to win 14 seats in the 2008 legislative elections (although this party was not joined by Park herself and its members would later re-join the GNP in 2010). A study of legislative voting between July 2008 and June 2010 found three distinct factions within the GNP - pro Lee (85), pro Park (59) and non-aligned (31) [27]. Lee's reforms did not become institutionalised or accepted by central party apparatus as a whole. The reversion to the old practice of renaming the party, as Park did in after becoming leader in February 2012 and subsequent scandals which brought about her impeachment, brings the role of leadership back into question. Lee was able to make leadership selection more progressive while re-affirming central leadership power over areas such as candidate selection (see below). The process of stabilising the party and the role of the leadership is still, in the words of Han, "an on-going process" [27].

\section{Candidate Selection}

\section{The LDP}

Under the Single Non-Transferable Vote system in Japan, electoral district battles were often fought between LDP candidates, with financing and resources depended on factional affiliation. Without factional backing, a candidate had little hope of being able to secure resources from government that would allow them to win votes and defeat better financed candidates from the same party. However, candidates were also highly reliant on non-party organisations, for both financing and campaign 
organisation, known as koenkai, district-based groups affiliated by the support for a political candidate but not official organs of any political party. This includes business, neighbourhood associations and networks of personal connections. Through fundraising on a semi-permanent basis and vote mobilisation at election times, the koenkai built personal ties with their supported candidate - not with the political party itself. The candidate then used their position in the party, usually through factional membership, to access government spending projects for their district [28]. Many of these koenkai were subsequently passed down through family connections to be taken over by younger generations. ${ }^{5}$ Also, through PARC, lawmakers were able to liaise with policy-specific interest groups and receive additional funding from outside normal party means. Candidates had little or no reliance on central party organisation, which could not favour competing candidates from the LDP in the same SNTV district, so local connections built up by the candidate through personal ties or even hereditary succession, as well as factional support, were the main drivers of LDP candidate selection [3]. Perhaps most importantly, the LDP was able to attract the best and brightest candidates as the economic boom of post-war Japan made it electorally the dominant party. Serious career advancement and continued benefit provision to constituents could only be made as a member of the LDP and one of its factions [6].

Electoral defeat in 1993 coincided with growing demands for electoral reform which would eventually lead to a Mixed Member Majoritarian system, made up of 300 Single Member District seats and 200 Proportional Representation seats, being adopted from the 1996 general election [29]. With the elimination of multiple candidates from the same party competing in the same district, factional power over candidate selection has decreased. Along with finance reforms, which will be expanded upon in the next section, electoral reform made candidates less reliant on factional backing. The practice of "inheriting" positions in politics has continued. In 1996, 37\% of LDP candidates elected to office were related to former lawmakers, while many others had been drawn from the ranks of the civil service [30]. Again, the 2005 election provides the exception to traditional forms of candidate selection and has not become institutionalised. Facing widespread internal opposition to post office privatisation, Koizumi used his power as party head to withdraw official party nomination from 32 LDP lawmakers who had voted against the government and effectively expel them from the party. However, Reed [20] highlights the highly pragmatic position taken by the LDP. Candidates who already had support bases, such as inherited koenkai, were mostly able to retain their seats running as independents and eventually welcomed back into the party. In reality, candidate selection remains, with the exception of the 2005 general election, a decentralised process.

\section{GNP/Saenuri}

Before free and fair elections in 1987, South Korea also used the SNTV system with two seats contested in each district. However, the then ruling Democratic Justice Party ${ }^{6}$ rarely ran more than one candidate in a district as it had authoritarian control over the

\footnotetext{
${ }^{5}$ As an example, current Prime Minister Shinzo Abe's grandfather was Prime Minster and father Foreign Minister

${ }^{6}$ The Democratic Justice Party (DJP), Democratic Liberal Party (DLP) and New Korea parties were precursors to the GNP/Saenuri. From here onwards, GNP/Saenuri will be used to denote these parties and their historical predecessors
} 
much more powerful executive branch [31]. With political office tied to the ability to provide clientelistic benefits rather than the desire for political or policy influence, especially in the dominant DJP/DLP party, candidate nomination was wholly in the hands of party leadership. Prospective candidates were reviewed by party officials and recommendations to the party president, who had final veto, were made. With access to state resources dependent on their ability to secure office and thus maintain clientelistic networks, it was not unusual for prospective candidates to "donate" money directly to party leadership in order to secure party nomination [32]. Electoral reform in 1988 which led to a combination of SMD seats and PR did little to change the top-down status quo. Candidate nomination, as with party policy, was tied directly to party leadership.

From the end of GNP dominance in 1997, two significant changes within party procedure affected the candidate nomination process. After Kim Young-sam exited the political area, political parties across the spectrum engaged in intra-party reform. The GNP, suffering from the public perceptions of corruption and a lack of progressive thinking, was forced to follow Roh Moo-hyun's Millennium Democratic Party in holding primaries for both local and National Assembly elections [33]. By 2004, the GNP Party Convention was officially responsible for candidate nomination and the GNP was actively working to make candidate selection a more open process. Local level primaries were introduced and public opinion polls became an influential factor. In the 2004 National Assembly election, $46.8 \%$ of GNP candidates were standing for the first time in an attempt to breakdown individual clientelistic networks [34]. This is not to discount the influence that factions filling the vacuum left by Kim had. Factions still had a great deal of influence in candidate selection, with resource provision being a valuable aid to any prospective candidate [32]. However, these attempts to move the candidate nomination process into the era of intra-party contestation were overturned by Lee Myung-bak in 2008. Candidate selection for the National Assembly elections of that year was put in the hands of a centralised nominating committee, which was under no obligation to justify its rejection of candidates or make selections with any transparency. The committee was made up of 11 members, 6 coming from business or NGO's and 5 coming from the party itself. While Lee could not directly control the nominating process, this system gave more influence to the party leader, who was responsible for appointing committee members [35]. As a result, the aforementioned split with the pro-Park faction was intensified and would contribute to the later split within the GNP. This method of candidate nomination continued within the Saenuri party, where the party's Supreme Council, elected by the National Convention, had final decision over the selection process. $^{7}$ Again evidence points to the re-centralisation of party decision making and a failure to institutionalise down-up party processes that would fit the catch-all model.

\section{Party Financing and Voter Affiliation}

\section{The LDP}

Candidate financing during the 1995-system was highly decentralised. Candidates and incumbent lawmakers had primarily decentralised sources of financing and resource

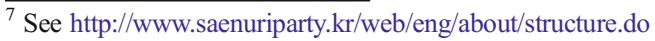


provision. The first came from the candidate centred koenkai. Fundraising included selling tickets to social events such as trips to hot springs or amusement parks or events which would lead to direct face time with the candidate. During its time of dominance, the LDP party was never able to replace the koenkai organisations and instead chose accept them as a de facto organ of the party, albeit ones which lay outside its control [3]. As an example of their financial importance, Fukui and Fukui reported that former Prime Minister Tanaka had in the region of 10,000 separate organisations with individual monthly membership fees of $¥ 10,000^{8}$ [36]. However, koenkai were not just a means for campaign finance but also acted "as a transmission belt for communicating the needs and interests of its members to the candidate" [37]. In somewhat of a contrast to other liberal democracies, this personalised base of support for candidates ensured that voter loyalty remained in the hands of the candidate and not the party. It was not unusual for LDP candidates to receive votes from individuals affiliated with other parties due to koenkai membership or the candidates' previous success at resource provision for voters in their district. Thus, the LDP at grassroots level has always been weak in comparison with other liberal democracies [29]. While factions played a less important role than koenkai, it should also be noted that under the SNTV system, financial support could make a crucial difference, especially for first time candidates who had no existing support network, to LDP candidate success when running against other LDP-backed candidates [38].

In the wake of the Lockheed Martin and Recruit Cosmos scandals of the 1970s and 1980s, financial corruption was the leading issue coming into the 1993 election. ${ }^{9}$ Campaign finance reform was finally undertaken by the LDP government in 1999. With the change to a Mixed Member Majoritarian system, with districts featuring only one candidate from the LDP, party identification has become more important. With changes in technology, the central party apparatus is now able to reach out to voters directly and claim credit for public works projects and other benefits brought on both a local and national level [36]. In addition, campaign finance reforms provided public funding to parties of $¥ 250$ per vote gained in the previous election. It also prevented businesses from contributing to koenkai, while allowing party branches no cap on amounts donated to them. A study by Carlson [39] breaks down LDP member's expenses and finds that in 2005 state subsidies and direct political contributions made through LDP affiliates only made up $63.4 \%$ of an average lawmaker's annual income, the rest still being made up through koenkai activities and loans. An additional challenge has been brought about by voter dissatisfaction seen through a drop-in voter turnout, just 59.6\% in 1996 from $67.3 \%$ in 1993 [23]. The national role of the party has not become institutionalised as the main actor in party affiliation or campaigning. Instead of empowering the central party apparatus, the LDP simply redrew its koenkai boundaries along the lines of new electoral boundaries and voter loyalty transferred to new LDP candidates. Moreover, Curtis points out that weakening social cohesion has led to a decrease in influence of local LDP politicians [2]. In areas of natural LDP support, i.e. non-urban areas, decreasing youth population and weakening social networks have left local organisations with less "hard" votes to rely on. As a result, candidates have an even greater reliance on their koenkai networks at the expense of

\footnotetext{
${ }^{8}$ Prime Minister from July 1972 to December 1974

${ }^{9}$ For more information, see Curtis 1999, pp. 70-77
} 
local party organisations. As one anonymous LDP lawmaker stated in 2007: "if I leave everything to the LDP organisation, chances might be that I lose the next election" [3].

\section{GNP/Saenuri}

The key to understanding the early stages of party politics in Korea is the regional basis that the major political parties were founded on. Gyeongsang province located in the east of the country was the birthplace of some of Korea's authoritarian era presidents such as Park Chung-hee (1962-1979) and Chun Doo-hwan (1980-1988). The DLP and its predecessors gained voter support based almost entirely on regional cleavage and the power of resource control to win swing voters in unaffiliated provinces such as Seoul [40]. The regional basis for party support continued into and after the "three Kim's era". In 1997, when the GNP candidate Lee Hoi-chang was defeated, the GNP won $61 \%$ of the vote in Gyeongsang but averaged only $26 \%$ in the rest of the country [41]. Affiliation was also strengthened by the fact that party membership incurred no direct fee, which saw membership (of the then New Korea Party) peak at around three million in 1996 [25]. Donations to the party were then accrued from individuals and businesses in whose interest it was to ensure continuing economic benefits to their region. By taking credit for the economic growth of the 1980s and 1990s combined with a reluctance to enforce economic oversight, the GNP and its predecessors were viewed as the party of business favoured by the chaebol companies ${ }^{10}$ [42]. Table 3 shows GNP voter share in presidential elections from three different regions in Korea-the traditional conservative base of Gyeongsang, the base of more progressive parties, such as the National Congress and Millennium Democratic Party, in Honam and the capital city Seoul, usually seen as a "swing" area.

While the GNP/Saenuri have begun to make some inroads into areas previously under opposition control and urban areas where it was previously weak, regional affiliation continues to be a major factor in voter-party identification. However, authors such as and Moon and Jhee argue that all parties in Korea are becoming more policy orientated, focusing on themes such as the economy and corruption $[43,35]$. The GNP/ Saenuri has also attempted to broaden its grassroots linkages through fostering relationships with civil society groups. Two examples are the New Right Union (NRU), founded in 2005, a national group made up of conservative Christians, veterans, business and the media, and the Korean Parent Federation, founded 2006, which opposes teacher and student strikes. Both organisations have acted as vote mobilisers and the NRU can claim conservative politicians, including former President Park, amongst their membership [44]. Financing continues to come chiefly from a combination of party leadership and state subsidies. In 2006, the GNP had a registered total of over 1 million members but only around $25 \%$ of those actually contributed to party financing in the form of fees [45]. In the same year, state subsidies made up $42.9 \%$ of income, much higher than in previous years as a result of 2004 amendments to the Political Fund Act which made it illegal for business to contribute directly to political parties. However, since 2004, when state subsidies were worth 1800 Won per voter, funding has been cut to 800 Won in non-national election years. For the GNP, the reduction of subsidies and stricter finance laws saw its income drop to 70,087 million

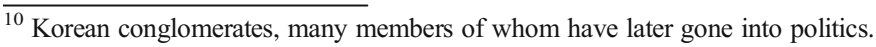


Table 3 Percentage of GNP/Saenuri votes in presidential elections in selected regions

\begin{tabular}{lcccccr}
\hline Region & 1987 & 1992 & 1997 & 2002 & 2007 & 2012 \\
\hline Gyeongsang & 52.6 & 67.47 & 58.88 & 67.67 & 57.93 & 65.69 \\
Honam & 9.03 & 4 & 3 & 4.8 & 8.93 & 10.32 \\
Seoul & 30.3 & 36.4 & 40.9 & 44.96 & 53.2 & 48.18 \\
\hline
\end{tabular}

Source: Korean National Election Commission

Won in 2006 down from 228,673 million Won in 1996 [46]. Individual lawmakers are becoming more reliant on local networks in order to raise the funds to fight increasingly expensive election campaigns and are more likely to be the target for donations. The result of this is that while party leadership still has overall control over candidate nomination and policy direction, its control over its lawmakers and local members has weakened $[25,46]$.

\section{Ideological Positioning and Policies}

According to Kirchheimer, development into a catch-all party involves both "deidealising" the party and concentrating on popular national issues which appeal beyond traditional party cleavages. In addition to this, as opposition parties the LDP and Saenuri would be expected to provide "moderate" opposition to the governing party by extending their appeal to the political centre [13]. To test this theory, the following section will use data from the Comparative Party Manifesto Database (CMP) to identify party positions on a range of policies and to test whether parties have adapted their policies and therefore ideational position to become closer to both other mainstream parties prioritising broad appeal-based policies over time.

\section{Ideological Positioning of Parties}

The degree of party polarisation can have a profound impact on the political system. As a rule, countries which have a high degree of polarisation are more likely to suffer from greater political instability, affecting the quality of democracy [14]. Using the Laver-Budge [47] model of right-left political scale, the CMP takes data from party manifestoes and attributes a value on the right-left ideological scale (RILE) based on 26 variables used in the survey, based on four core areas of policy - economic policy, social policy, decentralisation of decision making and environmental policy.

Figure 1 shows the course of the LDP's ideological position on the CMP RILE index in comparison to its main opposition party. ${ }^{11}$ In the case of the LDP in recent elections, with the exception of 2003, the party has kept within a consistent centrist policy platform. Both the LDP and the main opposition party consistently exhibit a high degree of pragmatism. With the exception of the 2000 and 2003 elections, the LDP has

\footnotetext{
${ }^{11}$ From 1993 and 1996, this was the Japanese Socialist Party, from 1998 onwards the Democratic Party of Japan
} 


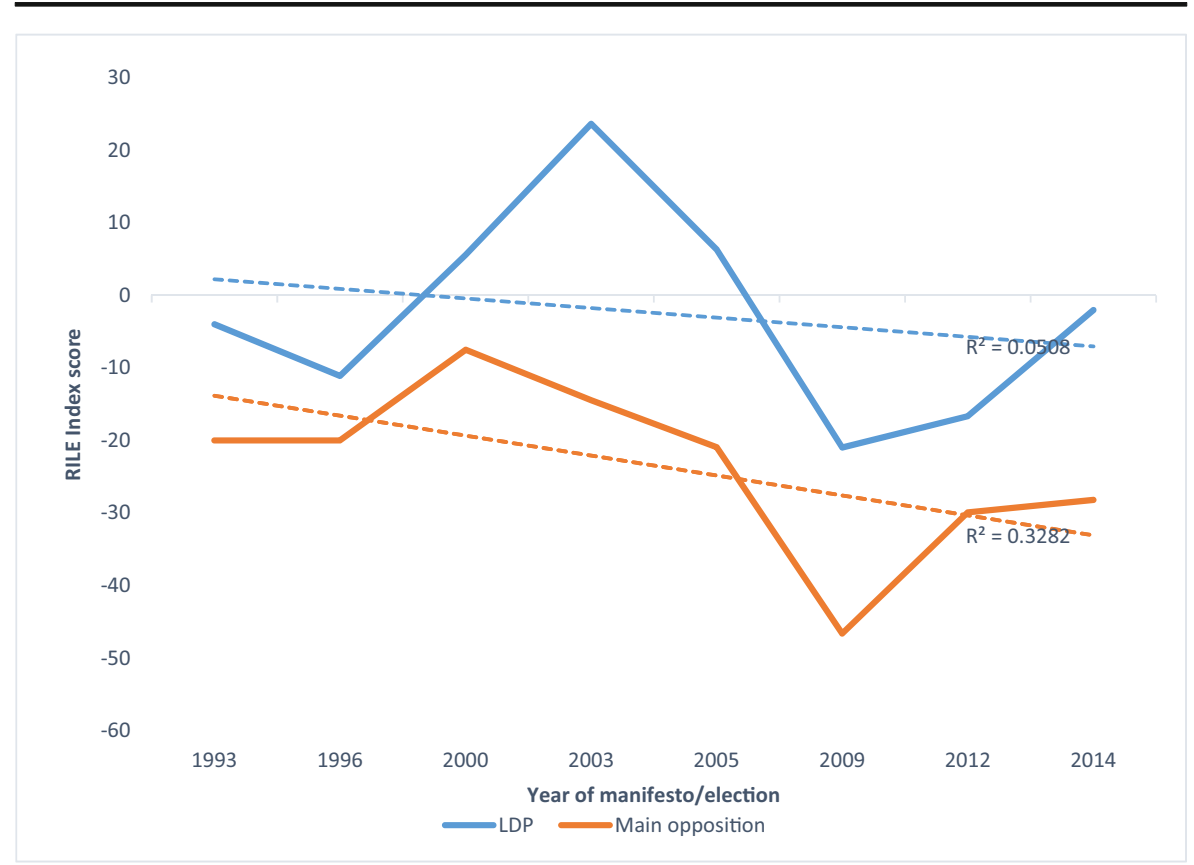

Source: Comparative Manifesto database

Fig. 1 Ideological position (on RILE index) of LDP and main opposition party since 1993 Source: Comparative Manifesto database

been closer to the centre than its main opposition party on the RILE index while often changing position dramatically from the previous election. This can be seen in elections between 1996 and 2000 and 2005-2009, in which LDP policies change almost in sync with the main opposition party while always remaining ideologically to the right. This shows both the LDP and main opposition parties, in vying to capture a majority of legislative seats, promoting policies in which are not radically different from each other, a practice envisaged by Kirchheimer, Duverger and Satori. The $R^{2}$ value $(0.0508)$ shows that since 1993 the LDP has, gradually moved to the left ideologically, but overall maintained manifesto platforms in the political centre ground.

Figure 2 shows a consistent move from the centre ground to an increasingly left ideological position in the years following the end of dominant party rule exhibited by the Saeunri party and its predecessors $\left(R^{2}=0.3731\right)$. When the GNP was in opposition to the executive, in the 2000 and 2004 legislative elections, there was a leftward trend to the party's ideological position, while it remained more centre based in 1996 and 2008 when it already controlled the Presidency. In addition, the elections of 2004 and 2012, which show the greatest shift to the left, coincided with the leadership in the national Assembly of Park Geun-hye whereas the party was led into the 1996, 2000 and 2004 elections by Kim Young-sam, Lee Hoi-chang and Kang Jae-sop, respectively, and took a more centrist position. There is a suggestion here of the influence of personality-based leadership, in this case of Park, directing the party in a less centrist direction [26, 27]. The CMP shows a significant rightward shift in the 2008 election, where welfare policies only made up $12.4 \%$ of the GNP manifesto compared to $27.5 \%$ in 2004 . In comparison with the main opposition parties, with the exception of 2008, the GNP moved itself both leftwards and closer in line 


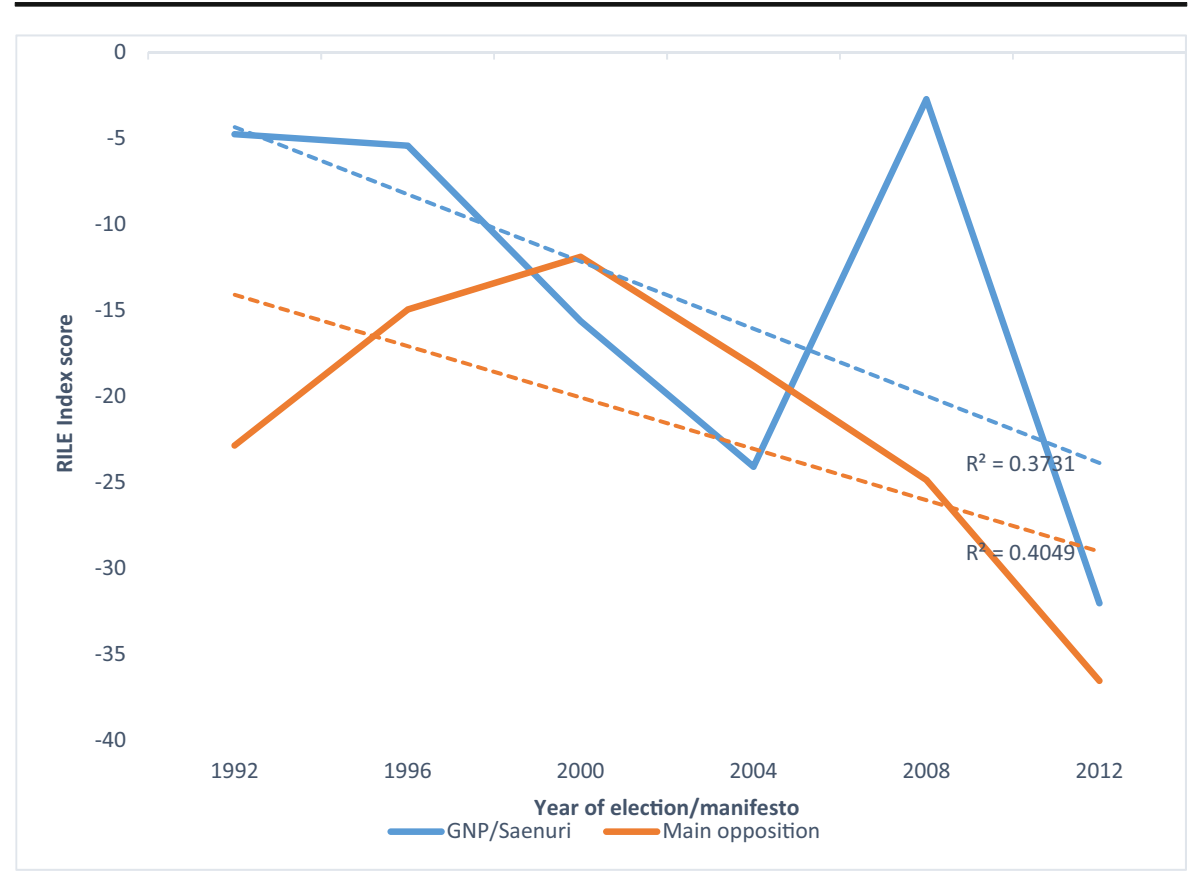

Source: Comparative Manifesto database

Fig. 2 Ideological position (on RILE index) of GNP/Saenuri and main opposition party since 1992 Source: Comparative Manifesto database

with its main rivals. This can clearly be seen when the GNP was in opposition in the 2000 and 2004 National Assembly elections where the party moved leftwards of the opposition Millennium Democratic and Uri parties, respectively. As with the LDP in Japan, this shows both pragmatism and a general trend of the GNP moving policy positions in line with those of its main rivals for political power.

Most Favoured Policies.

Table 4 shows the three most important policy areas for the LDP between 1990 and 2014 as listed in the CMP. From 1990, issues of Internationalism and political corruption played a large role in the LDP manifesto. ${ }^{12}$ This trend continued after the LDP's first defeat in 1993 until 2005, with foreign relations being the most important issue in the 1996 manifesto but after 2005 welfare issues and political and economic reform became core LDP policies. ${ }^{13}$ In addition, the range of issues covered by the LDP's manifesto has become much more diversified over time. For example, in 1990, the issue of environmental protection is not mentioned at all but from 2000 on it has made up between 3.61 and $8.33 \%$ of manifesto coverage. CMP data shows the percentage of manifesto coverage given pro-agricultural issues, support for one of the LDP's traditional support base has dropped, being the third most important manifesto issue in the 1990 election (12.25\%) but only the sixth most important issue in 2012 (5.42\%) not featuring at all in 1993 and 1996.

\footnotetext{
${ }^{12}$ Internationalism described in the CMP codebook as support for international institutions, cooperation and foreign aid

13 Technology and Infrastructure described in CMP codebook as importance of industrial and technological development
} 
Table 4 Top three most important policies by percentage coverage according to LDP manifesto

\begin{tabular}{|c|c|c|c|}
\hline Year & Most important issue & Second & Third \\
\hline 1990 & $\begin{array}{l}\text { Internationalism } \\
\quad \text { (positive)-14.28\% }\end{array}$ & Political corruption- $14.28 \%$ & $\begin{array}{l}\text { Agriculture and } \\
\text { farmers- } 12.25 \%\end{array}$ \\
\hline 1993 & Internationalism (positive)- $20 \%$ & Political corruption- $-12 \%$ & Political authority $-12 \%$ \\
\hline 1996 & $\begin{array}{l}\text { Foreign relations } \\
\quad(\text { positive })-22.22 \%\end{array}$ & $\begin{array}{l}\text { Government } \\
\text { efficiency-13.33\% }\end{array}$ & Economic goals-13.33\% \\
\hline 2000 & Military (positive)- $13.89 \%$ & Decentralisation- $11.11 \%$ & Productivity- $-11.11 \%$ \\
\hline 2005 & Education expansion- $-11.31 \%$ & $\begin{array}{l}\text { Government } \\
\text { efficiency-10.4\% }\end{array}$ & Law and order $-10.4 \%$ \\
\hline 2009 & Welfare expansion- $-14.86 \%$ & $\begin{array}{l}\text { Government } \\
\quad \text { efficiency-12.16\% }\end{array}$ & $\begin{array}{l}\text { Technology and } \\
\text { infrastructure- }-9.12 \%\end{array}$ \\
\hline 2012 & $\begin{array}{l}\text { Technology and } \\
\text { infrastructure }-15.86 \%\end{array}$ & Welfare expansion-14.86\% & Education expansion- $6.42 \%$ \\
\hline 2014 & $\begin{array}{l}\text { Technology and } \\
\quad \text { infrastructure- }-18.32 \%\end{array}$ & Incentives $-9.67 \%$ & Welfare expansion- $7.89 \%$ \\
\hline
\end{tabular}

Source: Comparative Manifesto database

The GNP/Saenuri follows a similar pattern (Table 5). Welfare, while always an important issue, had risen in its overall rate of representation in GNP/Saenuri manifestos from $7 \%$ in 1992 to a high of $26.13 \%$ in 2004 . This high mark for welfare issues came at a time when the GNP/Saenuri was in control of neither the executive or legislative branches of government and, while welfare is viewed as a more populist issue, its continued importance through 2008 and 2012 identify it as having become a core policy area. While the range of issues covered in their manifesto has always been larger than that of the LDP, there is a constant core of social and economic issues at the forefront of the GNP/Saenuri manifesto from 2000 onwards. Some explanation of significant ideological position change seen between 2008 and 2012 (Fig. 2) can be

Table 5 Top three most important policies by percentage coverage according to GNP/Saenuri manifesto

\begin{tabular}{|c|c|c|c|}
\hline Year & Most important issue & Second & Third \\
\hline 1992 (DLP) & $\begin{array}{l}\text { Technology and } \\
\text { infrastructure- } 13.9 \%\end{array}$ & Agriculture and farmers- $-9.6 \%$ & Welfare expansion-7\% \\
\hline 1996 (NKP) & Farmers-14.82\% & $\begin{array}{l}\text { Incentive (economic } \\
\text { enterprise)-11.75\% }\end{array}$ & $\begin{array}{l}\text { Technology and } \\
\quad \text { infrastructure- }-11.14 \%\end{array}$ \\
\hline 2000 (GNP) & Welfare expansion- $13.49 \%$ & Education expansion-10.67\% & $\begin{array}{l}\text { Neo-economic } \\
\text { groups }-8.32 \%\end{array}$ \\
\hline 2004 (GNP) & Welfare expansion- $-26.13 \%$ & Incentives $-7.43 \%$ & $\begin{array}{l}\text { Technology and } \\
\quad \text { infrastructure- }-7.21 \%\end{array}$ \\
\hline 2008 (GNP) & Incentives-17.63\% & Welfare expansion- $-13.44 \%$ & $\begin{array}{l}\text { Technology and } \\
\quad \text { infrastructure }-8.72 \%\end{array}$ \\
\hline 2012 (Saenuri) & Welfare expansion-19.9\% & Education expansion- $-10.2 \%$ & $\begin{array}{l}\text { Labour groups } \\
\qquad \text { (positive) }-7 \%\end{array}$ \\
\hline
\end{tabular}

Source: Comparative Manifesto database 
seen in the inclusion of education and support for labour groups, never before featured as core issues for the GNP, in 2012. Also, as with the LDP, CMP data shows that the traditional GNP/Saenuri base of agricultural issue support has seen a sharp decline from a high of $14.82 \%$ in 1996 to $3.9 \%$ in 2012 .

\section{Conclusion}

This study has found that, in terms of party organisation, there has been little institutionalised change in both the LDP and GNP/Saenuri parties. Those traits which do fit into the catch-all model, such as candidate nomination in the LDP or strong leadership and party affiliation in the GNP/Saenuri, are traits both parties have carried over from their time as dominant parties and have proven to be decisive factors in electoral success. However, it cannot be argued that party organisation has consciously adapted to closer fit a catch-all model and that changes in both parties have been pragmatic, temporary and un-institutionalised.

It is in the area of policy in where changes in both the LDP and GNP/Saenuri can be observed. Since the beginning of this century, both have begun to put more emphasis on social policies, such as welfare and education expansion and technological/ infrastructure reforms - policies focused on economic growth. This has come at the expense of policies which favour formerly traditional support bases, such as agriculture. When seeking endorsement at the ballot box, there is little doubt that these two parties are now consistently seeking "votes through broad issue appeal". In terms of policy promotion at least, the formerly dominant parties of Japan and South Korea can be categorised as catch-all. Further research of this type into East Asian political parties would provide an interesting insight into political developments in the region as a whole and add to studies charting the continuing democratisation of countries formerly under dominant party control.

Open Access This article is distributed under the terms of the Creative Commons Attribution 4.0 International License (http://creativecommons.org/licenses/by/4.0/), which permits unrestricted use, distribution, and reproduction in any medium, provided you give appropriate credit to the original author(s) and the source, provide a link to the Creative Commons license, and indicate if changes were made.

\section{References}

1. Kirchheimer, O, (1966) "The transformation of the Western European party systems," in Political parties and political development, Princeton, N.J: Princeton University Press, pp. 177-200.

2. Curtis G, The logic of Japanese politics : leaders, institutions, and the limits of change, New York: Columbia University Press, 1999.

3. Krauss E and Pekkanen $\mathrm{R}$, The rise and fall of Japan's LDP : political party organizations as historical institutions, Ithaca, N.Y: Cornell University Press, 2011.

4. Kim B, (2008) "Defeat in victory, victory in defeat: the Korean conservatives in democratic consoloidation," In Political transitions in dominant party systems: learning to lose, Abingdon, New York, Routledge, pp. 169-187.

5. Freidman E and Wong J (2008), Political transitions in dominant party systems: learning to lose, Abingdon: Routledge.

6. Pemple T, Uncommon Democracies: The One-Party Dominant Regimes, Ithaca: Cornell University Press, 1990. 
7. Trocki C (2005), Singapore: wealth, power and the culture of control, London: Routledge; Curzon.

8. Lipset S and Rokkan S (1967), Party systems and voter alignments: cross national perspectives, New York: Free Press.

9. McAllister I, (2008) "Social structure and party support," in Party politics in East Asia: citizens, elections, and democratic development, Boulder: Lynne Rienner Publishers, pp. 69-94.

10. Diamond L, and Gunther R, Political parties and democracy, Baltimore: Johns Hopkins University Press, 2001.

11. Panebianco A, Political parties : organization and power, Cambridge: Cambridge University Press, 1988.

12. Sartori G (1976), Parties and Party Systems, Cambridge: Cambridge University Press.

13. Duverger M, Political parties: their organization and activity in the modern state, London: Methuen, 1964.

14. Dalton R and Tanaka A, (2008) “The patterns of party alignment," In Party politics in East Asia: citizens, elections, and democratic development, Boulder: Lynne Rienner Publishers, pp. 27-48.

15. Diamond L, Plattner M and Yun-han C, Democracy in East Asia, Baltimore: John Hopkins University Press, 2013.

16. Huntington S, The third wave: democratization in the late twentieth century, Norman ; London: University of Oklahoma Press, 1991.

17. Kam C, Party discipline and parliamentary politics, Cambridge: Cambridge University Press, 2009.

18. Wolinetz S, "Beyond catch-all parties: Approaches to the study of Political Parties and Party Organisation in Contemporary Democracies," in Political parties : old concepts and new challenges, Oxford: Oxford University Press, 2002, pp. 136-165.

19. Babb J, "The New Generation of Conservative Politicians in Japan," Japanese Journal of Political Science, Vol 14 Issue 3, pp. 355-378, 2013.

20. Reed S, "The Liberal Democratic Party: an explantion of its sucesses and failures, London, Routledge: In Routledge handbook of Japanese politics, 2011, pp. 14-23.

21. Shinoda T (2011), "Prime Ministerial Leadership," in Routledge handbook of Japanese politics , London, Routledge, pp. 48-59.

22. Maeda K (2007), "Has the Electoral System Reform Made," in Stanford Conference on Electoral and Legislative Politics, Tokyo.

23. Theis M, "Changing how the Japanese vote: The promise and pitalls of the 1994 electoal reform," in How Asia Votes, New York: Chatham House Publishers, 2002, pp. 92-117.

24. Wang Y, "The Pendulum Swings: Experiences from the LDP on Democratizing Party Leadership Selection,” Japanese Journal of Political Science 17 (1), pp. 106-127, 2015.

25. Hellmann O Political parties and electoral strategy:the development of party organization in East Asia, New York: Palgrave Macmillan, 2011.

26. Park C, "Elections in democratising Korea," in How Asia Votes, New York: Chatham House Publishers, 2002, pp. 118-146.

27. Han J, "Factional party politics in the Korean National Assembly," in Governmental changes and party political dynamics in Korea and Japan, Tokyo, Japan, Bokutakusha, 2012, pp. 351-371.

28. Ramsayer M and Rosenbluth F, Japan's political ma0072ketplace, Cambridge: Mass London Harvard University Press, 1997.

29. Gaunder A, "The institutional landscape of Japanese politics," in Routledge handbook of Japanese politics, London, Routledge, 2011, pp. 3-13.

30. Stockwin J, Dictionary of the modern politics of Japan, London: Routledge Curzon, 2003.

31. Mo J and Brady D, "The SNTV and the politics of electoral systems in Korea," in Elections in Japan, Korea, and Taiwan under the single non-transferable vote: the comparative study of an embedded institution, Ann Arbor: University of Michigan Press, 1999, pp. 227-251.

32. Hellmann O, "Outsourcing canadidate selection: the figh against regionalism in East Asian politics," Party Politics. 20 (1), pp. 52-62, 2014.

33. Chung J (2008), "Reform of political parties," in Political change in Korea , P aju-si, Korea , Jimoondang, pp. 91-99.

34. Shin E (2005), "Electoral democracy: Populism and generational politics," East Asia Vol. 22 Issue. 1, pp. 51-81, Spring.

35. Jeon Y (2008), "A plan of action to increase voter turnout," in Political change in Korea, Korea, Jimoondang, pp. 170-177.

36. Fukui H and Fukui S, "Campaiging forthe Japanese Diet," in Elections in Japan, Korea, and Taiwan under the single non-transferable vote: the comparative study of an embedded institution, Ann Arbor: University of Michigan Press, 1999, pp. 121-152. 
37. Woodall B, "Politics of reform in Japan's lower house," in Elections in Japan, Korea, and Taiwan under the single non-transferable vote: the comparative study of an embedded institution, Ann Arbor: University of Michigan Press, 1999, pp. 23-50.

38. Inoguchi T, Japanese politics: an introduction, Melbourne, Vic Abingdon Marston: Trans Pacific, 2005.

39. Carlson M (2011), "Money in Japanese politics: regulation and reform," in Routledge handbook of Japanese politics, London, Routledge, pp. 70-80.

40. Kang W (2012), "A fortuitous democratic consolidation?," in Governmental changes and party political dynamics in Korea and Japan, Tokyo, Japan, Bokutakusha, pp. 193-212.

41. Kwon H (2012), "Parties and voters: the electoral politics of unemployment in Korea," in Governmental changes and party political dynamics in Korea and Japan, Tokyo, Japan, Bokutakusha, pp. 251-279.

42. Horowitz S (2002), "Understanding the decline of the Chaebol Republic," East Asia vol.20 issue. 1, pp. 81-106, Spring.

43. Moon W, "Decomposition of regional voting in South Korea," Party Politics .11 (5), pp. 579-599, 2005.

44. Shin K, "The dilemma of Korea's new democracy in the age of neoliberal globalisation," 3rd World Quarterly 33:2, pp. 293-309, 2012.

45. Lee D 2008, "The dynamics of party politics in Korea," in Political change in Korea , P aju-si, Korea, Jimoondang, pp. 84-90.

46. Eom K, "Problems with state subsidies for political parties," in Political change in Korea , P aju-si, Korea, P aju-si, Korea, 2008, pp. 129-137.

47. Laver M and Budge I, Party policy and government coalitions, New York: St. Martin's Press, 1992.

\section{Online Resources}

48. Korean National Election Commission website, accessed 20/11/2014. Available: http://info.nec.go. $\mathrm{kr} /$ electioninfo

49. Liberal Democratic Party of Japan website, accessed 14/05/2015. available: https://www.jimin. jp/english/about-ldp/constitution/104146.html

50. Comparative Manifesto Database, available: https://manifestoproject.wzb.eu 